\title{
Enterobius vermicularis: Ancient DNA from North and South American Human Coprolites
}

\author{
Alena M Iñiguez/ ${ }^{+}$, Karl J Reinhard*, Adauto Araújo**, Luiz Fernando Ferreira**, \\ Ana Carolina P Vicente
}

Laboratório de Genética Molecular de Microorganismos, Departamento de Genética, Instituto Oswaldo Cruz-Fiocruz, Av. Brasil 4365, 21045-900 Rio de Janeiro, RJ, Brasil *School of Natural Resource Sciences, University of Nebraska, Lincoln, NE, USA **Escola Nacional de Saúde Pública-Fiocruz, Rio de Janeiro, RJ, Brasil

A molecular paleoparasitological diagnostic approach was developed for Enterobius vermicularis. Ancient DNA was extracted from 27 coprolites from archaeological sites in Chile and USA. Enzymatic amplification of human mtDNA sequences confirmed the human origin. We designed primers specific to the E. vermicularis $5 S$ ribosomal RNA spacer region and they allowed reproducible polymerase chain reaction identification of ancient material. We suggested that the paleoparasitological microscopic identification could accompany molecular diagnosis, which also opens the possibility of sequence analysis to understand parasite-host evolution.

Key words: ancient DNA - Enterobius vermicularis - coprolites

Based on several lines of evidence including archaeoparasitology and cladistic analysis, the pinworm Enterobius vermicularis is one of the most ancient parasites of humans and has a pre-hominid evolutionary origin (Ferreira et al. 1997, Hugot et al. 1999). Paleoparasitological studies showed the presence of pinworm eggs in 10,000-year-old human coprolites from United States and in coprolites from Chile and Peru dating from 2200 to 400 BC (Ferreira et al. 1997). In some prehistoric cultures, $E$. vermicularis reached very high prevalence as indicated by the numbers of coprolites that contain eggs (Reinhard 1998). Until now, diagnosis of pinworms in archaeological remains was dependent on microscopic examination. This is a particularly poor method of identifying prehistoric pinworm infections (Reinhard 1990, Araújo et al. 1998). Recent work revealing the ancient DNA (aDNA) of parasites such as Trypanosoma cruzi in mummies and Ascaris in coprolites (Ferreira et al. 2000, Loreille et al. 2001) opened this area of investigation to other organisms. This paper presents a molecular diagnosis of $E$. vermicularis using the conserved region from 5S ribosomal RNA (rRNA) intergenic spacer as target.

The coprolites $(n=27)$ from archaeological sites in Chile and North America were analyzed. Samples from Chile were collected in archaeological sites of Caserones $(\mathrm{n}=2)$, Tarapacá Valley, dating from $400 \mathrm{BC}$ to $800 \mathrm{AD}$ (Ferreira et al. 1984); of Tulan $(n=20)$, San Pedro de Atacama dating to $1000 \mathrm{BC}$ (Ferreira et al. 1989); and of Tiliviche $(\mathrm{n}=2)$ dated from 4110 to $1950 \mathrm{BC}$ (Araújo et al. 1983). USA samples $(n=3)$ were from Antelope House, an Anasazi village site in Canyon de Chelly, Arizona dating

This study was supported by ENSP-Fiocruz, IOC-Fiocruz and Fulbright Comission.

${ }^{+}$Corresponding author. Fax: +55-21-2260.4282. E-mail: alena@ioc.fiocruz.br

Received 26 August 2002

Accepted 25 November 2002 from $900 \mathrm{AD}$ (Reinhard 1996) (Table). DNA extraction and amplification were performed under the procedures established for working with aDNA to avoid contamination with modern molecules (Hofreiter et al. 2001, Marota \& Rollo 2002). The surface of the samples was exposed to UV light and the coprolite core was ground. Coprolite powder (5-2 g) was hydrated in $\mathrm{ddH}_{2} \mathrm{O}$ or TE buffer (Tris$\mathrm{HCl}$ 10mM, EDTA 1mM, pH 8.0). Coprolites, formerly used in microscopic diagnostic in $0.5 \%$ trisodium phosphate aqueous solution (Ferreira et al. 1989), also were analyzed. Sediments of $150 \mu \mathrm{l}$ were treated by $72 \mathrm{~h}$ with $400 \mu \mathrm{l}$ digestion buffer $(\mathrm{NaCl} 100 \mathrm{mM}$, Tris-HCl $50 \mathrm{mM}$, SDS 1\%, EDTA $50 \mathrm{mM}, \mathrm{pH} 8.0$ ), and added $20 \mu \mathrm{LTT} 1 \mathrm{M}, 60 \mu \mathrm{l}$ proteinase $\mathrm{K} 10 \mathrm{mg} / \mathrm{ml}$ (Gibco BRL) and $100 \mu \mathrm{l} \mathrm{SDS10 \%}$. The reactions were incubated at $55-60^{\circ} \mathrm{C}$ for $3-24 \mathrm{~h}$ with occasional homogenization followed by the phenol/chloroform extraction and purified using silica resin column (Glass Max DNA Isolation Spring Cartridge System Gibco-BRL).

In order to determine the nature of the coprolites, human mitochondrial DNA (mtDNA) amplification was done using the procedure described by Pääbo (1990) and Handt et al. (1996). E. vermicularis amplification was performed by nested PCR targeting $E$. vermicularis $5 \mathrm{~S}$ rRNA spacer region: Entf (5'-CACTTGCTATACCAACAACAC-3') and Entr (5'-GCGCTACTAAACCATAGAG-3'); and internal Eva (5'-ACAACACTTGCACGTCTC-3') Evb (5'GAATTGCTCGTTTGC-3'). PCR final volume reaction was: $25 \mu \mathrm{l}$ using $20 \mathrm{mM}$ Tris- $\mathrm{HCl}, 0.5 \mu \mathrm{M} \mathrm{KCl}$ (Gibco BRL 10X Buffer), $2 \mathrm{mM} \mathrm{MgCl}$, $0.2 \mathrm{mM}$ each dNTPs, $1 \mathrm{mg} / \mathrm{ml}$ bovine serum albumin (BSA) and $500 \mathrm{ng}$ of each oligonucleotide. The mixture was exposed to $30 \mathrm{~min}$ UV radiation before the $2.5 \mathrm{U}$ of Taq polymerase (Gibco BRL) and 50100 ng DNA extract addition. The reactions were subjected to an initial cycle of $5 \mathrm{~min}$ at $94^{\circ} \mathrm{C}$, followed by 35 cycles of $94^{\circ} \mathrm{C}$ for $1 \mathrm{~min}, 50-55^{\circ} \mathrm{C}$ for $30 \mathrm{sec}$ and $72^{\circ} \mathrm{C}$ for $30 \mathrm{sec}$ in a programmable thermal controller (PTC100 60v, MJ Research, Inc). Extraction and negative PCR controls were included. Amplicons were hybridized with a radiolabeled probe from the same region amplified from a modern sample (Sambrook et al. 1989). 
Human mtDNA was retrieved from almost all coprolite samples by using Handt et al. (1996) procedure (Fig. 1). Due to the nature of aDNA, the target choice is a crucial step for the successful sequence retrieval. The complete pinworm highly conserved ribossomal $5 \mathrm{~S}$ intergenic region is about 800 bp (Liu et al. 1995), with several copies in an organism. We designed primers for a nested PCR targeting this region. The first and second primer pair produced $420 \mathrm{bp}$ and $198 \mathrm{bp}$ specific and unique amplicon, respectively. The control of primer specificity was done previously using DNA extracted from modern feces and E. vermicularis experimental coprolites (Iñiguez 1998). We were successful in the molecular paleoparasitological diagnosis of $E$. vermicularis using the specific pinworm $5 \mathrm{~S}$ rRNA spacer region (Fig. 2). The hybridization result confirmed the specific nature of the diagnostic bands with 198 bp length (data not shown). All positive samples in the microscopic analysis but nine were PCR positive. Two samples, 706 and 716, negative in the microscopic analysis, yielded E. vermicularis diagnostic amplicon (Table).
The sample 721 was PCR negative either to mtDNA or pinworm target. Considering that during this work the experimental procedure of DNA extraction, purification and the set up of PCR reactions, were done in two different laboratories and repeated at least twice, we concluded that the aDNA 721 was highly degraded (Lindahl 1993, Marota et al. 2002). In this regard, microscopic identification of pinworms eggs is still relevant for paleoparasitological diagnosis. However, molecular approach not only offers a precise identification, but also the opportunity of ancient parasite sequence comparisons with those of contemporary populations. Further analysis of human mtDNA and pinworm aDNAs sequences can provide more comprehension about E. vermicularis evolution and their human host.

\section{REFERENCES}

Araújo A, Reinhard KJ, Bastos OM, Costa LC, Pirmez C, Iniguez AM, Vicente ACP, Morel CM, Ferreira LF 1998. Paleoparasitology: perspectives with new techniques. Rev Inst Med Trop São Paulo 40: 371-376.

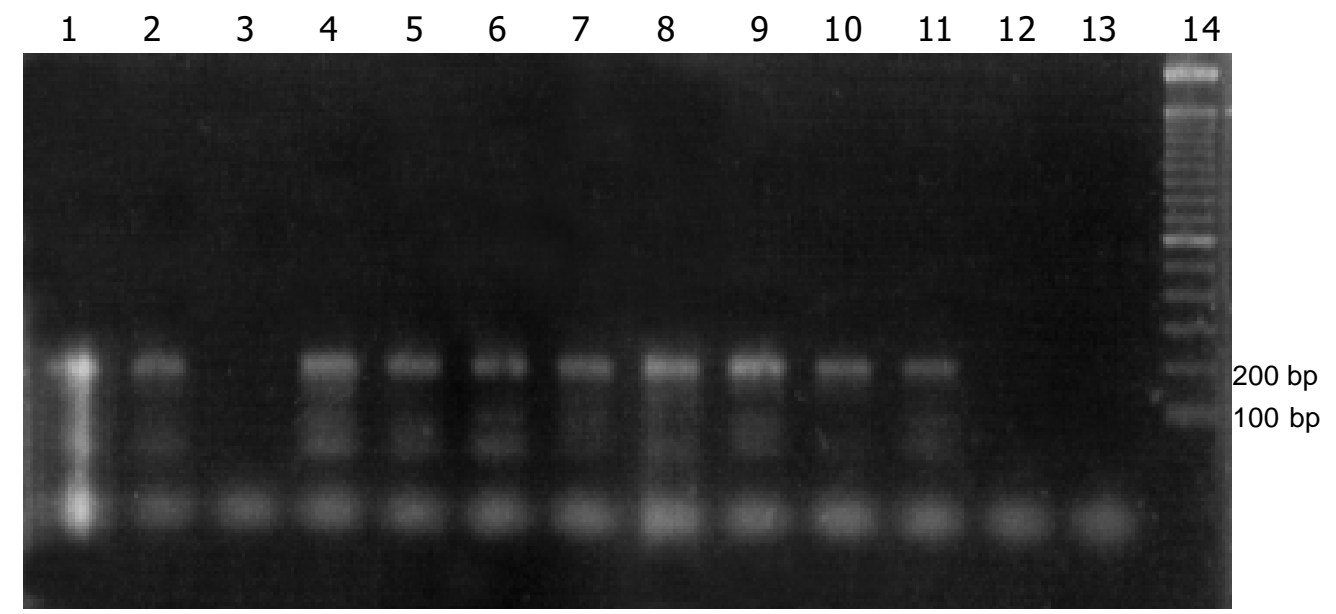

Fig. 1: mitochondrial human DNA amplicom (185 bp): Lanes - 1 to 12: coprolite samples: 168, 170, 384, 385, 704, 706, 708, 714, 715, 716, 719, and 721, respectively. Lane 13: PCR negative control; 14: 100 bp DNA ladder (Gibco BRL). (2 \% Agarose gel electrophoresis).

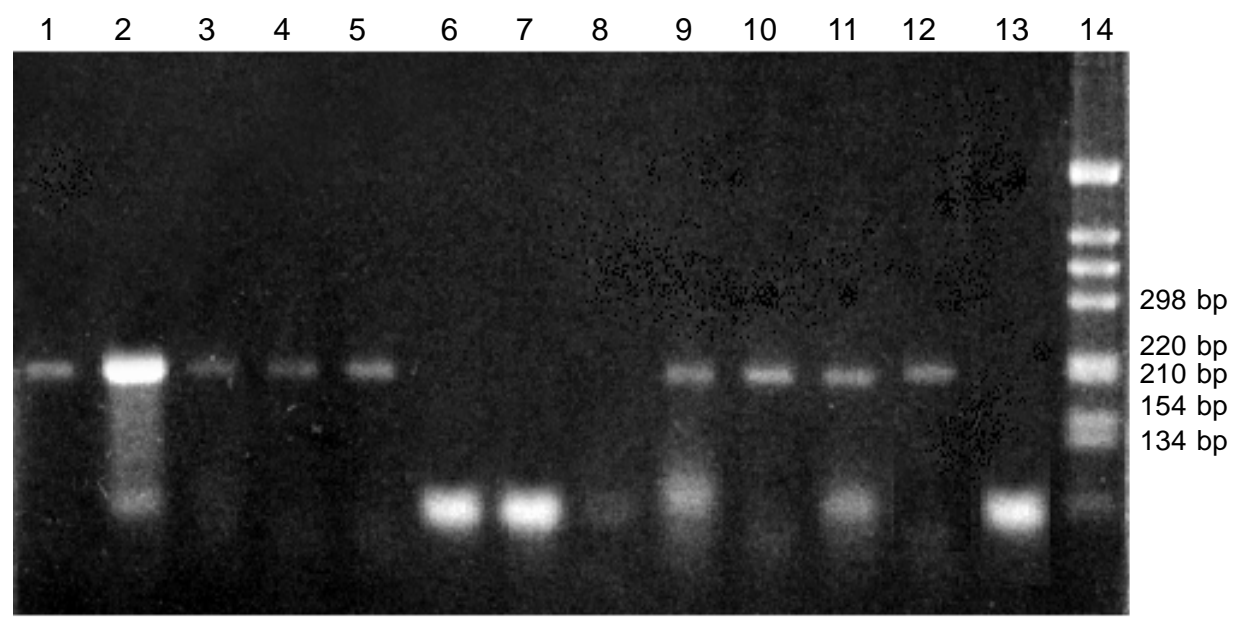

Fig. 2: Enterobius vermicularis diagnostic amplicon (198 bp). Lanes - 1 to 12: coprolite samples 170, 385, 704, 708, 714, 721, 168, 384, 706, 715, 716 and 719, respectively; 13: PCR negative control; 14: $1 \mathrm{~kb}$ DNA ladder (Gibco BRL). (2 \% Agarose gel electrophoresis). 
TABLE

Enterobius vermicularis microscopic and molecular paleoparasitological analysis

\begin{tabular}{|c|c|c|c|}
\hline Coprolite & Archaeological site & $\begin{array}{c}\text { Microscopic } \\
\text { analysis }\end{array}$ & $\begin{array}{c}\text { Molecular } \\
\text { analysis }\end{array}$ \\
\hline 168 & Tiliviche, Chile & - & - \\
\hline 170 & & + & + \\
\hline 384 & Caserones, Chile & - & - \\
\hline 385 & & + & + \\
\hline 704 & Arizona, USA & + & + \\
\hline 706 & & - & + \\
\hline 708 & & + & + \\
\hline 710 & Tulan, Chile & - & - \\
\hline $710 \mathrm{~A}$ & & - & - \\
\hline $710 \mathrm{~B}$ & & + & - \\
\hline $710 \mathrm{C}$ & & - & - \\
\hline 711 & & $++^{a}$ & - \\
\hline 712 & & + & - \\
\hline 713 & & + & - \\
\hline 714 & & $+a$ & + \\
\hline 715 & & + & + \\
\hline 716 & & - & + \\
\hline 717 & & - & - \\
\hline 718 & & + & - \\
\hline 719 & & - & + \\
\hline 720 & & + & - \\
\hline 721 & & + & - \\
\hline 722 & & + & - \\
\hline 723 & & - & - \\
\hline 724 & & + & - \\
\hline 725 & & - & - \\
\hline 726 & & - & - \\
\hline
\end{tabular}

$a$ : also positive for Trichuris trichiura

Ferreira LF, Araujo A, Confalonieri U, Nunez L 1989. Infecção por Enterobius vermicularis em populações agro-pastoris pré-colombianas de San Pedro de Atacama, Chile. Mem Inst Oswaldo Cruz 84:197-199.

Ferreira LF, Reinhard KJ, Araújo A, Coura LC 1997. Paleoparasitology of Oxyuriasis. An Acad Nac Med 157: 20-24.

Ferreira LF, Ribeiro B, Araujo A, Confalonieri U, Nunez L 1984. Enterobius vermicularis eggs in precolumbian human coprolites from Chile. Paleopathol Newsl 46: 4-5.
Ferreira LF, Britto C, Cardoso MA, Fernandes O, Reinhard K, Araújo A 2000. Paleoparasitology of Chagas disease revealed by infected tissues from Chilean mummies. Acta Trop 75: 79-84.

Handt O, Krings M, Ward RH, Pääbo S 1996. The retrieval of ancient human DNA sequences. Am J Hum Genet 59: 368376.

Hofreiter M, Serre D, Poinar HN, Kuch M, Pääbo S. 2001. Ancient DNA. Nature Reviews Genetics 2: 353-359.

Hugot JP, Reinhard KJ, Gardner SL, Morand S 1999. Human enterobiasis in evolution: origin, specificity and transmission. Parasite 6: 201-208.

Iñiguez AM 1998. Análise de DNA Ancestral para o Estudo de Infecções Parasitárias em Populações Pré-históricas, MSc Thesis, Fundação Oswaldo Cruz, Rio de Janeiro, 87 pp.

Lindahl T 1993. Instability and decay of the primary structure of DNA. Nature 362: 709-715.

Liu LX, Chi J, Upton MP, Ash LR 1995. Eosinophilic colitis associated with larvae of pinworm Enterobius vermicularis. Lancet 346: 410-2.

Loreille O, Roumat E, Verneau O, Bouchet F, Hanni C 2001. Ancient DNA from Ascaris: extraction amplification and sequences from eggs collected in coprolites. Int J Parasitol 31: 1101-1106.

Marota I, Rollo F 2002. Molecular paleontology. Cell Mol Life Sci 59: 97-111.

Marota I, Basile C, Ubaldi M, Rollo F 2002. DNA decay rate in papyri and human remains from Egyptian archaeological sites. Am J Phys Anthropol 117: 310-318

Pääbo S 1990. Amplifying ancient DNA. In MA Innis, DH Gelfand, JJ Sninsky, TJ White (eds), PCR Protocols: a Guide to Methods and Applications, Academic Press, San Diego, p. 159-166.

Reinhard KJ 1990. Archaeoparasitology in North America. Am J Phys Anthropol 82: 145-162.

Reinhard KJ 1996. Parasite ecology of two Anasazi villages. In EJ Reitz, LA Newson, SJ Scudder (eds), Case Studies in Environmental Archaeology, Plenum press, New York, p. 245-288.

Reinhard KJ 1998. Mummy studies and archaeoparasitology. In A Cockburn, E Cockburn, TA Reyman (eds), Mummies, Disease and Ancient Cultures, Cambridge University Press, Cambridge, p. 377-380.

Sambrook J, Fritsch E, Maniatis T. 1989. Molecular Cloning: A Laboratory Manual, 2nd ed., Plainview: Cold Spring Harbor Laboratory Press, Cold Spring Harbor. 